\title{
Empirical Analysis of Financial Risks of Corporate M\&A Based on Big Data
}

\author{
Xiao-xiao Deng* \\ School of Economics and Management, \\ Nanjing University of Science and Technology \\ Nanjing, Jiangsu Province, P.R. China \\ 1014538466@qq.com
}

\begin{abstract}
In order to study the relationship between goodwill and financial risk, and the role of corporate executives in controlling the relationship between the two, this paper took the 2013-2017 data of GEM listed companies as a sample, and used the statistical analysis tool of STATA. The paper firstly established the multiple regression model, then carried on the correlation analysis and the regression analysis, finally carried on the robustness test. The results show that there is a significant positive correlation between the merger goodwill and financial risk of the enterprise. In addition, executive holdings significantly weaken this positive correlation. What is unique about this paper is that few scholars use the "goodwill" of listed companies on the GEM as a variable to examine the relationship.
\end{abstract}

Keywords-Merger and acquisition goodwill; Financial risk; Salary incentive; The problem of agency.

\section{INTRODUCTION}

Since the split share structure reform in 2005, M\&A activities in China's capital market have become increasingly fierce. The "Opinions on Further Promoting the Healthy Development of the Capital Market" issued by the State Council in 2014, which propose to broaden the financing channels for mergers and acquisitions, enrich the payment methods for mergers and acquisitions, and respect the independent decision-making of enterprises. At the time of the country's overall economic downturn, the release of this policy has led to an increase in M\&A activity among enterprises, the number of GEM M\&A transactions reached 472 in 2015, and there was only one transaction in 2009. At the same time, the amount of business goodwill on the GEM kept growing, reaching 248.099 billion yuan in 2017, which accounted for $21.45 \%$ of net assets. The huge goodwill bubble led to the thunder of enterprise performance at the end of 2018, which brought heavy losses to enterprises and investors. The higher the goodwill of M\&A, the more difficult it is to benefit from M\&A [1]. Many scholars at home and abroad mainly studied from the aspects of the essential attributes, influencing factors, confirming measurement and economic consequences of goodwill. In terms of the essential attributes of goodwill, the famous "ternary theory" is still widely recognized [2]. About the influencing factors, Xingqiang Du et al. found that due to the existence of agency problems, goodwill is overestimated [3]. On the economic consequences of goodwill, Xinyuan Zhang and Yanjun Xu put forward the high cost of goodwill paid by listed companies significantly reduces the company's performance [4]. Chao $\mathrm{Fu}$ et al. found that the "excess return ability" of goodwill in M\&A is not significant in listed companies on GEM [5]. The existing literature on China's research on financial risk of mergers and acquisitions focuses on basic issues. Fei $\mathrm{Li}$ found that it is possible to respond to corporate financial risks by formulating a reasonable M\&A strategy, selecting scientific assessment methods, and setting maximum cash payment limits [6]. Ettore Croci and Dlmitris Petmezas found that due to the agency problem, managers may conduct worthless mergers and acquisitions for their own interests, or pay a higher takeover premium to the target company in order to obtain a higher management position, thereby damaging the value of shareholders of the acquiring company [7]. As the shareholding ratio of executives increases, their interests are consistent with the interests of shareholders, forming "convergence of interests" [8].

\section{ThEORETICAL ANALYSIS AND RESEARCH HYPOTHESIS}

\section{A. Corporate Mergers and Acquisitions Goodwill and Financial Risks}

Some scholars suggested that goodwill is a total price account that contains various difficulties, which are difficult to interpret. Therefore, if the enterprise is not properly acquired, goodwill will often become the "depository place" for managers' decision-making mistakes and excess considerations, which will inevitably lead to the intensification of corporate financial risks [9].

The financial risks of M\&A mainly include pricing risk, financing risk, payment risk and financial integration risk. These four risks are not only related to each other, but also restrict each other, which jointly affect the financial risks of M\&A [10]. At the time of merger and acquisition, the methods of appraising enterprise value mainly include the income approach, the market approach and the cost approach. The choice of evaluation parameters depends largely on the professional judgment of the assessors, which leads to greater pricing risk. The acquirer's estimate of the target company's value is too high, and the payment consideration exceeds its own capacity. This leads to the merger's inability to enhance the competitiveness of the company and drag down the operation of the company [11]. Compared with the cash payment method, stock payment can effectively reduce the 
financial risk and information asymmetry risk caused by mergers and acquisitions [12]. In the case of M\&A of GEM companies, a lot of enterprises have higher valuations. Most M\&A transactions are directly priced according to the evaluation price. According to the data of Minsheng Securities Research Institute, the M\&A value of GEM in 2013-2017 is 753\%,540\%,476\%, 780\%, 592\% respectively. More than $90 \%$ of corporate M\&A payments are made by cash payment. A large amount of cash paid by enterprises has led to a decrease in the liquidity of corporate assets, which has led to serious and unreasonable capital structure and inevitably exacerbates the financial risks of enterprises. The higher the M\&A premium, the greater the goodwill impairment in the later period [13]. Based on the above analysis, this paper proposes hypothesis 1:

Hypothesis 1: Under the same other conditions, there is a significant positive correlation between acquisition of goodwill and corporate financial risk.

\section{B. Corporate Mergers and Acquisitions Goodwill, Financial Risks and Executive Holdings}

According to Xingqiang Du et al, the overestimation of goodwill often comes from the existence of agency problems [3]. The shareholder acts as the principal and the manager acts as the agent. Stege moller $\mathrm{M}$ et al. Pointed out that because the objective functions of the two are inconsistent, the manager who has the information advantage may maximize self-interest by damaging the interests of the shareholders [14]. In M\&A activities, executives' holdings are beneficial for managers to combine their own interests with corporate interests. Executives can not only carefully handle M\&A transactions, but also carefully select the target companies that are suitable for the company's development and expansion. In the end, this measure can restrain the abnormal high amount of goodwill to some extent, thus reducing the financial risk.

The executive shareholding of GEM listed companies have a positive correlation with the company's performance, and the company's financial performance has increased with the increase of management's shareholding ratio. Jianwei Zhang found that there is a positive correlation between executive stock ownership and corporate performance in listed companies on GEM [15].

Hypothesis 2: Under the same other conditions, Executive holdings have a significant weakening effect on the positive correlation between acquisition goodwill and corporate financial risk.

\section{RESEARCH DESIGN}

\section{A. Source of Data}

This paper selects the data of the listed companies on GEM from 2013 to 2017. The data is selected from the CSMAR database. The data of listed companies in the financial industry, ST enterprises, and enterprises with a net goodwill of 0 at the end of the period, and obviously singular samples were excluded. After the above processing, a total of 739 enterprises meet the requirements, a total of 1531 samples were obtained, and the extreme values were processed by winsorizing.
Correlation analysis and regression analysis were performed using STATA software.

\section{B. Selection of Research Variables}

\section{- Dependent variable}

Financial risk (Z). This paper selects the "Z-Score" model proposed by American scholar Altman [16] in the 1960s and predicts the financial crisis of enterprises through the total discriminant scores generated by the weighted summary of various financial indicators.

- Independent variables

Goodwill (GW), Executive shareholding ratio (TOPHOLD). In order to better conform to the research design of this paper, the senior management includes directors, supervisors and general managers according to the viewpoints of Xueli Wang [17].

\section{- Control variables}

The size of the board directors(INBD), the proportion of independent directors(INDR), the chairman and general manager concurrently(DSZ), the top three executive compensation(GGX), company size(SIZE), return on assets(ROA), equity ratio(ER), internal control(ICMW). In addition, this paper sets two dummy variables for industry and year.

\section{Empirical Model}

On the basis of hypothesis 1 , this paper will verify the positive correlation between goodwill and financial risk. And this paper takes the net goodwill at the end of the period of the consolidated financial statements as the independent variable, and the financial risk calculated according to "Z-Score" model used as the explanatory variable. Equation (1) as following

$\mathrm{Z}=\beta_{0}+\beta_{1} \mathrm{GW}+\beta_{2} \mathrm{SIZE}+\beta_{3} \mathrm{ER}+\beta_{4} \mathrm{ROA}+\beta_{5} \mathrm{INBD}+\beta_{6} \mathrm{INDR}+\beta_{7} \mathrm{GG}$ $\mathrm{X}+\beta_{8} \mathrm{ICMW}+\beta_{9} \mathrm{DSZ}+\sum \mathrm{Ind}+\sum$ Year $+\varepsilon$

On the basis of hypothesis 2, this paper will verify the adjustment effect between executive stock holdings on corporate goodwill and financial risk. The interaction term GW*TOP of executive stock holdings and goodwill is added to the model to establish Equation (2)

$\mathrm{Z}=\beta_{0}+\beta_{1} \mathrm{GW}+\beta_{2} \mathrm{TOPHOLD}+\beta 3 \mathrm{GW} * \mathrm{TOP}+\beta_{4} \mathrm{SIZE}+\beta_{5} \mathrm{ER}+\beta_{6} \mathrm{R}$ $\mathrm{OA}+\beta_{7} \mathrm{INBD}+\beta_{8} \mathrm{INDR}+\beta_{9} \mathrm{GGX}+\beta_{10} \mathrm{ICMW}+\beta_{11} \mathrm{DSZ}+\sum \mathrm{Ind}+\sum \mathrm{Y}$ ear $+\varepsilon$

\section{EMPIRICAL RESULTS AND ANALYSIS}

\section{A. Correlation Analysis}

In this paper, the Pearson correlation coefficient test is performed between variables. It can be seen from the table that goodwill(GW) and financial risk(Z) are positively correlated, which significant at the $1 \%$ level. This result initially proves the hypothesis 1 . The interaction term GW*TOP of executive stock holdings and goodwill is negatively correlated with financial risk, which significant at the $1 \%$ level. This result initially proves the hypothesis 2 . 
TABLE I. CORRELATION ANALYSIS OF MAJOR VARIABLES

\begin{tabular}{|c|c|c|c|c|}
\hline & $\mathrm{Z}$ & $\mathrm{GW}$ & TOPHOLD & GW*TOP \\
\hline $\mathrm{Z}$ & 1 & & & \\
\hline GW & $0.229 * * *$ & 1 & & \\
\hline TOPHOLD & $-0.189 * * *$ & $-0.154^{* * *}$ & 1 & \\
\hline GW*TOP & $-0.149 * * *$ & 0.031 & $0.972 * * *$ & 1 \\
\hline
\end{tabular}

Note: $(1) * * * * *$ and $*$ mean significant at $1 \%, 5 \%$ and $10 \%$ respectively, the same below.

\section{B. Regression Analysis}

TABLE II. HYPOTHESIS 1 REGRESSION RESULTS

\begin{tabular}{|c|c|}
\hline & Equation (1) \\
\hline VARIABLES & $\mathbf{Z}$ \\
\hline GW & $\begin{array}{c}0.003 * * * \\
(2.678)\end{array}$ \\
\hline Size & $\begin{array}{c}0.048 * * * \\
(10.65)\end{array}$ \\
\hline ER & $\begin{array}{c}0.175^{* * *} \\
(15.805)\end{array}$ \\
\hline ROA & $\begin{array}{c}0.192 * * * \\
(23.813)\end{array}$ \\
\hline ICMW & $\begin{array}{c}-0.01 \\
(-1.477)\end{array}$ \\
\hline DSZ & $\begin{array}{l}0.009 * * \\
(2.149)\end{array}$ \\
\hline INBD & $\begin{array}{c}-0.011 \\
(-0.809)\end{array}$ \\
\hline INDR & $\begin{array}{c}-0.033 \\
(-0.746)\end{array}$ \\
\hline GGX & $\begin{array}{c}-0.036^{* * *} \\
(-8.885)\end{array}$ \\
\hline YEAR & CONTROL \\
\hline IND & CONTROL \\
\hline Constant & $\begin{array}{c}-0.376 * * * \\
(-3.899)\end{array}$ \\
\hline R-squared & 0.679 \\
\hline Observations & 1531 \\
\hline
\end{tabular}

Note: (1) t-statistics in parentheses, , the same below.

The above table shows the results of regression analysis of goodwill and financial risk. The regression $\mathrm{R}^{2}$ is 0.679 , which indicates that the model has a good fitting effect. The coefficient of goodwill is 0.003 . It is significant at the level of $10 \%$. Hypothesis 1 is established. This means that the higher the financial risk of the enterprise, the larger the capital involved in M\&A activities. In addition, the high premium of most M\&A results in huge goodwill. From the analysis of the previous article, it can be seen that most of the M\&A activities of listed companies on GEM are paid in cash, and the centralized payment of large amounts of cash leads to poor liquidity of funds and unbalanced capital structure, which further aggravates corporate financial risks. Corporate scale(SIZE) and financial risks are also positive correlated, indicating that the larger the total assets of the enterprise, the greater the financial risk. The total compensation of the top three executives(GGX) is negatively correlated with the financial risk of the enterprise. The coefficient is -0.036 , it shows that the higher the total compensation of top executives is, the lower the financial risk will be. The compensation incentive of enterprises has a significant effect on restraining the agency problem in M\&A activities, thus reducing the possibility of potential financial risks.

TABLE III. HYPOTHESIS 2 REGRESSION RESULTS

\begin{tabular}{|c|c|}
\hline & Equation (2) \\
\hline VARIABLES & $\mathbf{Z}$ \\
\hline GW & $\begin{array}{c}0.00377 * * \\
(2.23) \\
\end{array}$ \\
\hline SIZE & $\begin{array}{c}0.0412 * * * \\
(9.89)\end{array}$ \\
\hline ER & $\begin{array}{c}0.163^{* * *} \\
(21.33) \\
\end{array}$ \\
\hline ROA & $\begin{array}{c}0.208 * * * \\
(34.34)\end{array}$ \\
\hline INBD & $\begin{array}{c}0.00222 \\
(0.14) \\
\end{array}$ \\
\hline INDR & $\begin{array}{c}-0.0368 \\
(-0.68)\end{array}$ \\
\hline GGX & $\begin{array}{c}-0.0381 * * * \\
(-8.96)\end{array}$ \\
\hline ICMW & $\begin{array}{c}-0.0184^{* *} \\
(-2.54)\end{array}$ \\
\hline DSZ & $\begin{array}{c}0.0102 * * \\
(2.25)\end{array}$ \\
\hline TOPHOLD & $\begin{array}{c}0.0904 \\
(1.00)\end{array}$ \\
\hline GW*TOP & $\begin{array}{c}-0.00852^{*} \\
(-1.65)\end{array}$ \\
\hline YEAR & CONTROL \\
\hline IND & CONTROL \\
\hline Constant & $\begin{array}{c}-0.302 * * * \\
(-3.18) \\
\end{array}$ \\
\hline R-squared & 0.623 \\
\hline Observations & 1,531 \\
\hline
\end{tabular}

The regression results of equation (2) are shown in above. The coefficient of goodwill is 0.00377 , and it is significant at the level of $5 \%$. Further, it provides strong evidence for hypothesis 1, indicating that the M\&A goodwill and the corporate financial risk have a significant positive relationship. Equation (2) introduces a new independent variable-the interaction term GW*TOP of goodwill and executive holdings. With a coefficient of -0.00852 , it is significant at the $1 \%$ level. Hypothesis 2 is verified. Executive shareholding can significantly reduce the positive correlation between high goodwill and corporate financial risk. Equity incentives can alleviate agency problems in M\&A activities. Senior management and shareholders "convergence of interests." When managers have residual claims on the economic interests of enterprises, the management objectives of managers and shareholders tend to be consistent, which enhances the management's sense of ownership.

\section{RoBustness TEST}

In order to ensure the robustness of the empirical results, this paper referred to the views of Shouhua Zhou et al. [18], replacing the financial risk index of enterprises with the FScore model. On the basis of Z-Score model, the F-Score model takes the influence of cash flow into consideration when predicting the financial risks of enterprises, which makes up for the deficiency of Z-Score model. The result is consistent with 
the previous one, that is, goodwill is positively correlated with corporate financial risk, and it is significant at the level of $1 \%$. $\mathrm{GW}^{*}$ TOP-the interaction item between the goodwill and the shareholding of senior executives-has a negative regulating effect on the M\&A goodwill and the financial risk of the enterprise, and it is significant at the level of $1 \%$. The robustness test further ensures the reliability of the empirical results in this paper. The specific formula of F-Score is as follows:

$$
\begin{gathered}
F=-0.1774+1.1091 X_{1}+0.1074 X_{2}+1.9271 X_{3} \\
+0.0302 X_{4}+0.4961 X_{5}
\end{gathered}
$$

$\mathrm{X}_{1}=$ working capital/total assets

$\mathrm{X}_{2}=$ retained earnings/total assets

$\mathrm{X}_{3}=$ (net income after tax + depreciation)/average total debt

$\mathrm{X}_{4}=$ equity market value/total liabilities

$\mathrm{X}_{5}=$ (net income after tax + interest + depreciation)/average total assets

\begin{tabular}{|c|c|}
\hline VARIABLES & $\mathbf{F}$ \\
\hline GW & $\begin{array}{c}0.0809^{* * * *} \\
(6.37)\end{array}$ \\
\hline SIZE & $\begin{array}{c}0.367 * * * \\
(8.42)\end{array}$ \\
\hline ER & $\begin{array}{c}0.541 * * * \\
(8.44)\end{array}$ \\
\hline ROA & $\begin{array}{c}0.123 * * * \\
(4.18)\end{array}$ \\
\hline ICMW & $\begin{array}{l}-0.136 \\
(-1.63)\end{array}$ \\
\hline DSZ & $\begin{array}{l}-0.0176 \\
(-0.34)\end{array}$ \\
\hline INBD & $\begin{array}{c}-0.000324 \\
(-0.00)\end{array}$ \\
\hline INDR & $\begin{array}{l}-0.893 \\
(-1.46)\end{array}$ \\
\hline GGX & $\begin{array}{c}-0.273 * * * \\
(-5.68)\end{array}$ \\
\hline GW*TOP & $\begin{array}{c}-0.0382 * * * \\
(-4.35)\end{array}$ \\
\hline YEAR & CONTROL \\
\hline IND & CONTROL \\
\hline Constant & $\begin{array}{c}-171.5^{* * *} \\
(-3.65)\end{array}$ \\
\hline R-squared & 0.233 \\
\hline Observations & 1,531 \\
\hline
\end{tabular}

TABLE IV. REGRESSION RESULTS OF ROBUSTNESS TEST

\section{CONCLUSION}

Through Pearson correlation test and regression analysis, the following conclusions are drawn: (1) M\&A goodwill has a significant positive correlation with corporate financial risk; (2) Executive shareholding has negative adjustment to the positive correlation between goodwill and financial risk effect. Although high goodwill will increase financial risk, companies can improve this situation through incentives for executives. Before an M\&A activity begins, the company should reasonably choose to acquire the target company. At the same time, the company should use the scientific asset assessment method to evaluate the merger target and reduce the amount of goodwill. The company can use the equity and cash hybrid payment method to avoid a large amount of liquid assets outflow. In addition, companies that focus on the encouragement of senior management and formulate appropriate equity incentive policies will have a positive impact on the performance of companies before and after mergers and acquisitions.

\section{REFERENCES}

[1] Harford J. Corporate cash reserves and acquisitions[J]. The Journal of Finance, 1999, 54(6):1969-1997.

[2] Hendrickson. compiled by Wang Danru and Chen Jinchi. Accounting theory by Eldon s Hendrickson [M]. Shanghai: Lixin Accounting press, 2013.

[3] Du Xingqiang, Du Yingjie, Zhou Zejiang. Discussion on the connotation and recognition of goodwill [J]. Accounting research, 2011 (01) :1116+95. (In Chinese)

[4] Zhang Xinyuan, Xu Yanjun. Thoughts on accounting treatment of goodwill—case analysis on impairment of goodwill based on 263 [J]. Finance and accounting, 2017, (17):28-30. (In Chinese)

[5] Fu Chao, Wang Jingyi, Fu Daiguo. Is M\&A goodwill exaggerated from scratch? -Based on the empirical evidence of A-share listed companies [J]. China's economic problems, 2016 (06):109-123. (In Chinese)

[6] Li Fei, Research on financial risk control strategy in enterprise merger and acquisition activities[J]. Business accounting, 2018(23):26-28. (In Chinese)

[7] Ettore Croci, Dlmitris Petmezas. Do risk-taking incentives induce CEOs to invest? Evidence from acquisitions. Journal of Corporate Finance. 2015(32): 1-23.

[8] Marchica M T, Mura R. Direct and ultimate ownership structures in the UK: an intertemporal perspective over the last decade[J]. Corporate Governance: An International Review, 2005,13(1): 26-45.

[9] Wang Yuexiang. Research on the impact of M\&A premium on goodwill impairment [D]. Beijing Jiaotong University, 2017. (In Chinese)

[10] Li Jintan, Li Hongkun. Financial risk analysis and prevention of enterprise merger and acquisition [J]. Economic Research Guide, 2012 (03): 50-57. (In Chinese)

[11] Canning, John B. The Economics of Accountancy[M]. New York: A New York Times Company, 1929.

[12] De Cesari A, Gonenc H, Ozkan N. The effects of corporate acquisitions on CEO compensation and CEO turnover of family firms[J]. Journal of Corporate Finance, 2016(38): 294-317.

[13] Moeller S B, Schlingemann F P, Stulz R M. How do diversity of opinion and information asymmetry affect acquirer returns[U]. Review of Financial Studies, 2007, 20(6):2047-2078.

[14] Officer M S, Poulsen A B, Stege moller M. Target-firm information asymmetry and acquirer returns[J]. Review of Finance, 2008, 13(3): 467493.

[15] Zhang Jianwei. Research on the relationship between executive stock ownership and corporate performance of Listed Companies -- Taking GEM listed companies as the research object [D]. Xi'an University of construction technology, 2015. (In Chinese)

[16] Altman e. I. Financial ratios, discriminant analysis and the prediction of corporate bankruptcy[J]. The journal of finance, 1968, 23(4): 589-609.

[17] Wang Xueli, Ma Lin, Wang Yanli. Influence of functional background of executive team on corporate performance: a case study of listed companies in China's information technology industry [J]. 2013: 93-105. (In Chinese)

[18] Zhou Shouhua, Yang Jihua, Wang Ping. 1996. On Early Warning Analysis of Financial Crisis-F-Score Model. Accounting Research, 1996, (008):8-11. (In Chinese). 